\title{
COMMUNITY PARTICIPATION FOR THE EDUCATION IN PESANTREN MADINATUL MUNAWWARAH BUKITTINGGI
}

\author{
Junaidi \\ State Institute for Islamic Studies of Bukitinggi (IAIN Bukittinggi) \\ Jl. Gurun Aua Kubang Putih Agam Regency, West Sumatera \\ E-mail: alhady.junaidi@yahoo.co.id
}

\begin{abstract}
Abstrak: Partisipasi Masyarakat Terhadap Pendidikan di Pesantren Madinatul Munawwarah Bukittinggi. Penelitian ini bertujuan untuk melihat bentuk-bentuk partisipasi masyarakat dalam perencanaan dan pelaksanaan pendidikan di Pesantren Madinatul Munawwarah Bukittinggi, faktor-faktor yang mempengaruhi partisipasi masyarakat serta upaya yang dilakukan pihak pesantren berkenaan dengan partisipasi masyarakat di Pesantren Madinatul Munawwarah Bukittinggi. Penelitian ini merupakan penelitian kualitatif yang deskriptif dengan menggunakan observasi dan wawancara sebagai alat pengumpulan data. Hasil penelitian menunjukkan bahwa bentuk partisipasi masyarakat pada perencanaan dan pelaksanaan pendidikan di Pesantren Madinatul Maunawwarah Bukittinggi baru berupa materi/barang, uang dan tenaga. Bantuan itu pun bukan sepenuhnya datang dari masyarakat sekitar pesantren, tapi lebih banyak dari para donator diluar masyarakat sekitar pesantren terebut. Sedangkan partisipasi berupa ide, usulan, kritikan dan saran persentasenya masih rendah. Adapun faktor-faktor yang menyebabkan masyarakat kurang berpartisipasi terhadap perencanaan dan pelaksanaan pendidikan di Pesantren Madinatul Munawwarah adalah faktor kesibukan pekerjaan, faktor lokasi pesantren yang terletak di tengah-tengah masyarakat yang heterogen (umumnya pendatang), tingkat pendidikan masyarakat juga menjadi faktor yang mempengaruhi. Upaya untuk meningkatkan partisipasi masyarakat terhadap pendidikan di pesantren melalui: mengajak dan menghimbau masyarakat, memberikan kesadaran kepada masyarakat tentang pentingnya sekolah agama dan juga melibatkan masyarakat pada beberapa kegiatan serta melalui tokoh-tokoh yang berpengaruh di masyarakat.
\end{abstract}

Kata kunci: partisipasi; masyarakat; pendidikan.

\begin{abstract}
Community Participation For The Education In Pesantren Madinatul Munawwarah Bukittinggi. This research aims to explore the forms of community participation in educational planning and implementation in Pesantren Madinatul Munawwarah Bukittinggi, influencing factors for this participation and school board efforts regarding to the community participation in Pesantren Madinatul Munawwarah Bukittinggi. This research is a descriptive qualitative study with observation and depth interview in collection data. the findings above, The forms of the community participation for education in Pesantren Madinatul Munawarrah is in the form of material, money, and physical assistance. These participation is not entirely from the surrounding community but from the donator outside them. On the other hand, the participation in the form of ideas, suggestions, and criticisms is still low. Factors influencing the lack participation of the community in the Pesantren Madinatul Munawwarrah is the factor of profession, the location of the pesantren in heterogonous community (mostly inhabited by temporary settlers), and the level of education. The efforts to increase the community participation for education in the pesantren are through involving the community in many events or activities, raising their awareness about the importance of the pesantren, and involving important public figures in the community.
\end{abstract}

Keywords: participation; community; education.

\section{Introduction}

Pesantren is established in Indonesia due to the demand and needs of society. Therefore, it allows the community participation to take place in the school intensively. The participation is manifested in various forms, from the provision of physical facilities to the provision of budget needs, and so forth. A pesantren plays its role as the fulfillment for the community demands and needs for education and guidance of life 
guide. Therefore, the high level of community participation has put the pesantren and its kiai (religious figure) as the center or core of their social life. ${ }^{1}$ As the center of the social life, the pesantren and its kiai become the determining factor for the social dynamics or changes in the community. Conversely, the continuity of the pesantren highly depends on the extent of community participation and some services it provides as demanded by the community.

Imran explains ${ }^{2}$ that the participation of the community in the implementation of the related policies not only viewed as the loyalty for the government but also viewed as important as their own.Through their sense of belonging toward the related policies, the community will contribute more to their implementation, including the implementation of educational policies.

Participation can serves as a bridge between the government as the power, authority, and policy makerand the community with their civil rights, political and socio economic conditions. Irene asserts that for a pesantren community participation for educational development is an objective reality in which its awareness or understanding is determined by the subjective condition of the parents. ${ }^{3}$ Thus, participation requires a common understanding or objectivation from the pesantren and the parents regarding to the goals of the pesantren. It means that it does not suffice for the pesantren to consider the participation as the most important part for the success in improving its quality because achieving the desired quality will be difficult if the intersubjective domains (students, parents, and parents) show the performance gap in their understanding of that given quality. Sam \&Tuti, further explains that the participation also gives the broad opportunity for the community

\footnotetext{
${ }^{1}$ Abuddin Nata, Sejarah Pertumbuhan dan Perkembangan Lembaga-lembaga Pendidikan Islam Indonesia. (Jakarta: PT.Grasindo Gramedia Widiya Sarana Indonesia, 2001), p.144.

2 Ali Imron, Kebijaksanaan Pendidikan Di Indonesia (Jakarta: BumiAksara, 2002), p.79-80.

3 Siti Irene Astuti Dwiningrum, Desentralisasidan Partisipasi Masyarakat Dalam Pendidikan, (Yogyakarta: PustakaPelajar, 2011). p. 192.
}

to play roles in education, so it shows that the state is not a sole administrator of the education. ${ }^{4}$

As a social institution, a pesantren highly depends on the community participation. The good and bad development of the pesantren is largely determined by the level of community participation for this institution.

One of the pesantrens that also needs community participation is Pesantren Madinatul Munawwarah Bukittinggi. The current condition in this pesantren shows the low level of participation from the surrounding community. It can be seen from; 1) low community participation in the provision of physical facilities, 2) low community participation in attending in any activities that involve them, 3) lack of community involvement in planning the programs for the pesantren and its budget provision, 4) the community fully relies on the school administrators to do all the works.

\section{Theoritical Review \\ 1. Participation}

The success of a program or activity depends on the participation. Participation is one of the characteristics of a good official performance. In the Dictionary of Sociology "Social Participation", is defined as a situation in which a person feels himself and others as the result of social interaction. However, according to Keith Davis in his book "Human Relational Work" "participation is defined as mental and emotional involvement of a person in a group situation roomates ecourages him to contribute to group goals and share responsibility in them". "The above definition implies that the participation is not only in physical form but also in the emotional and mental one and it also demands the full responsibility for the running program.

According Yusufhadi Miarso ${ }^{7}$ participation

${ }^{4}$ Sam M. Chan, Tuti T. Sam, .Kebijakan Pendidikan Era Otonomi Daerah, (Jakarta: Raja GrafindoPersada, 2015), p. 118.

5 Gordon Marshall, A Dictionary of Sociologi, (Oxford University Press: New York, 1998), h. 30.

${ }^{6}$ Keith Davis, Human Relation Work, terj, Agus Darma, Perilaku dalam Organisasi, ( Jakarta: Erlangga, 1996), p. 179.

7 Yusufhadi Miarso, Menyemai Benih Tekhnologi 
is a spontaneous involvement of mind, energy, goods or money followed by the responsibility for the group interest to achieve desired goals. This definition contains three ideas: involvement, contribution and responsibility. Furthermore, Miarso explains, involvement is the mental and emotional engagement which not only show physical involvement but also show mental involvement. Contribution is the provision of an opportunity to channel one's initiative and creativity to achieve organizational goals. Finally, responsibility is one's obligation to carry out what has been mandated to him.

Verhangen in Danang states that participation is a special form of interaction and communication related to the establishment, authority, responsibility and benefits. ${ }^{8}$ Different from this, Jnabrabota Bhattacharyya in Ndraha defines participation as taking part in commonplace activities. Further, he said that the failure to achieve the goal of the developmental programs is caused by the lack of community participation. ${ }^{9}$

Hence, participation is a condition or state in which an individual or group of people actively involve themselves physically or mentally in a certain program or an activity, and develop a sense of team or group with full responsibility.

\section{Community}

The term "community" used in this study refers to the one proposed by Page Mac Iver who assert that it is a system of customs and traditions of authority and cooperation among the various groups and the classification of behavioral control and human freedoms. These whole changing aspects are called community. Community is the social relationship, which is always changing. ${ }^{10}$ Soekanto proposes the followings as the elements of community ${ }^{11}$ : a

\footnotetext{
Pendidikan, (Jakarta: Kencana, 2004), h. 56.

8 Danang Prihartanto, "Partisipasi Masyarakat dalam Pengembangan Obyek Wisata (Studi Deskriptif tentang Pengembangan Proyek Wisata Air Terjun Jumogi di Desa Berjo)", 2007), h. 21.

9 Taliziduhu Ndraha, Pembangunan Masyarakat Tinggal Landas, (Jakarta: Penerbit Rineka Cipta, 1990), h.

10 RM.Mac Iverdan Charles P, Society an Introductory Analysis, (Macmillan\&Co. Ltd), 1961.

"Soerjono Soekanto, SosiologiSuatuPengantar, Edisi Baru
}

system that consists of a variety of components including popu In short, community lation, culture, material culture, social organization and social institutions and systems, all of which have common goal and inhabit the same area as well.

\section{Community Participation}

Community participation is the word combination of "community" and participation. According to Yusufhadi Miarso these two word combinations contains a number of ideas and references, both from each word and from the combination. The implied idea is the participation of all members or related elements in implementing a common shared interest or work, which is intended to facilitate the achievement of the desired goals. On the other hand, the references contained in this combination is the ground or a meeting forum with its openness to discuss the issues, the interaction to formulate goals and find out the best way to achieve them, the decision made together, and the monitoring or planning execution.

Community participation in education has the following goals:

a. To form community awareness about their shared responsibility for education.

b. To implement mutual cooperation between the concerned parties in education.

c. To achieve effectiveness and efficiency in the utilization of human, natural, and artificial resources such as fund, facility, and regulation.

d. To improve school performance which also means the improvement of productivity, access to education, harmonious process, and educational outcomes corresponding to students and environmental conditions and commitment from educational administrators. ${ }^{12}$

Furthermore, Miarso explains that community participation in education in this era decentralization is a the manifestation of

Keempat, ( J a k a rt a : Rajawali Pers,1990), p. 21.

${ }^{12}$ Yusufhadi,Miarso, Menyemai Benih..., p. 709. 
public awareness to the existence of educational institutions to create high qualified human resources.

\section{Legal Foundations for Community Participation in Education}

The government will not likely be able to implement education without the participation or support from the community. Therefore, it needs a legal foundation governing community involvement in the development of the educational sector in particular and the national development sector in general.

The Director General for Islamic Education stated the strategy in developing the Islamic education based on the field of education policy (2015-2019) "In increasing the Islamic education management, all the stakeholders should upgrade their participations in developing and improving the effectiveness of education organizer to support school in giving the services".

Law No. 20 Year 2003 on National Education System mentions of the community, state government and local government in education, some of which:

a. In article 6 of National Educational System Regulation, it is mentioned that "every citizen is responsible for the continuity of education"

b. In article 8 of National Educational System Regulation, it is mentioned that "community has a right to participate actively in the process of planning, implementation, monitoring, and evaluation of educational program.

c. In article 8 of National Educational System Regulation, it is mentioned that "community must give their support in the educational process.

Article 6,8 and 9 state that the community has the right and obligation to participate in the success of education. Some of their rights are to participate actively in the process of education in school from creating school vision and mission to determining the curriculum that is suitable to the local characteristics.
Their obligations are to give support in the process of education in school through participation in providing related resources that the school does not have such as staff, ideas, books, learning media, and educational fund. It corresponds to article 46 section 1 of National Educational System Regulation that states "the funding for education is the shared responsibility of the state government, local government, and local community."

From this article, it can be implied that the source of educational funding does not only belong to the state and local governments, but also belong to the community. Thus, the education is financed by state and local government and the community. It corresponds to the article 54 section (1) and (2) on National Educational System Regulation:

(1) The role of the community in education includes the participation of individual, group, familiy, professional organization, businesspeople, and community organization in the administration and quality control of educational services.

(2) The public can participate as the source, executioner, and user of educational outcomes.

\section{Forms of Community Participation}

There are several forms of community participation. According to Ericson in Slamet, the participation the community can give can be in the form of three stages ${ }^{13}$ :

1) Participation in idea planning stage. Participation in this stage means the involvement of a person in the phase of formulating the planning and strategies in arranging committee and budget for a certain activity/ project. The community participates through giving suggestions, recommendations, and critics in the meeting conducted;

2) Participation in implementation stage. Participation in this stage means the

13 Slamet, Y, Pembangunan Masyarakat Berwawasan Partisipasi, (Surakarta: Sebelas Maret University Press,, 1994), p.89. 
involvement of a person in the implementation stage of a project. In this phase, the community can provide help, money, material and ideas as one form of their participations in the given project;

3) Participation in utilization stage. Participation in this stage means the involvement of a person in the utilization phase of a project after it is completed. The community participation in this stage is in the form of providing help and money to operate and maintain the project that has been complete.

The community participation is expressly mentioned in the Decree of the Minister of Education No. 044 / U / 2002, regarding Educational Board and Committee for Pesantren. Both play roles as ${ }^{14}$ :

1. Advisory agency in the process of formulating and implementing educational policies;

2. Supporting agency for financial, ideas, or help in administrating education;

3. Controlling agency to achieve transparency and accountability of educational administration and outcome;

4. Mediator of the government and the parliament with the community.

\section{Factors Influencing Community Participation}

Factors influencing community participation consists of the factors from within the community (internal), the ability and willingness of the community to participate, and factors from outside the community (external), the involvement of existing formal institutions. The community ability is relate to their social stratification. These factors can be explained as follows ${ }^{15}$ :

1) Internal factors

Internal factors come from within the community itself, the individual and the group in it. The individual behavior is closely related to and determined by sociological characteristics such as age, sex,

${ }^{14}$ Hadiyanto, Mencari Sosok Desentralisasi Manajemen Pendidikan di Indonesia, (Jakarta: RinekaCipta, 2003), p. 86.

${ }^{15}$ Slamet, Y, PembangunanMasyarakat..., p.97. knowledge, job and income. Theoretically, there is a relationship between the individual characteristics and the level of their participation. Age, educational level, occupation, their duration in the community, the amount of income, and the involvement in development activities will greatly affect community participation.

According to Plumer in Suryawan, some of the influencing factors for the community participation are: a) Knowledge and expertise; The basic knowledge they have will affect the whole environment of the community. It determines whether people understand or not about their stages and types of participation; b) Profession; Usually, people with certain professional level will be able or not be able to spend their time to participate in a particular project. Often, the common excuse for the community participation is that there is a contrast between the working commitment is fundamental to society is the contradiction between working commitment and desire to participate.; c) level of education and literacy; This factor is very influential for the willingness and ability of the community to participate, to understand and to implement their level and type of participation; d) Sexes; It is well known fact that most people still think that this is most determining factor of participation since men and women have different perception and view toward certain subject matter; e) Belief toward a particular culture; Community with a high degree of heterogeneity, especially in terms of religion and culture, will determine the strategies and methods of their participation. Often, their belief contradicts with the existing concepts.

2) External factors

According to Sunarti ${ }^{16}$, these external factors can be understood as the stakeholder, all interested parties who have influence in the

${ }^{16}$ Sunarti, Partisipasi Masyarakat dalam Pembangunan Perumahan secara Kelompok, Jurnal Tata Loka.Semarang: Planologi UNDIP, 2003. 
given program. Key stake holders the one with the most significant influence or with the most important position for the success of the given program.

\section{Efforts to Improve Community Participation in Education}

Community participation is the real involvement in a certain activity. This articipation can be in the form of ideas, constructive criticisms constructive, and support for the educational implementation.

According to Mulyasa ${ }^{17}$, there are some efforts to mobilize community participation in education. First, proposing sanctions against those who are not willing to participate in the form of penalty, fine, and other losses. Second, proposing rewards to those who want to participate. Third, persuading the community to participate for their own benefits, both in short and in long term. Fourth, informing the community about various school activities. Fifth, correlating the community with the good school services. Sixth, asking an influence public figure to participate in school activities. Seventh, correlating the community participation in school activities with their interests. Eighth, raising the community awareness to participate in many school activities to actualize their aspirations.

\section{Research Method}

This research is a descriptive qualitative study because it will explore thetypes and the factors that influence community participation in the planning and implementation of education and the efforts made to improve this participation in Pesantren Madinatul Munawwarah Bukittinggi.

The data for this study use were collected through the library research technique. In this library research, the writer attempted to examine a number of library documents such as books, magazines, newspapers, laws, regulations and other related documents relevant to the

${ }^{17}$ Mulyasa, Manajemen Berbasis Sekolah (Konsep, Strategi dan Implementasi), (Bandung: Remaja Rosdakarya,2006), p. 150. issues examined. The field research is aimed to conduct the study directly in the location and object defined. The field research was conducted through observation that is the direct observation of the studied object of direct observation and direct interview with the informants. ${ }^{18}$

Informants in this study are divided into two, key informant and supporting informant. The key informant in this study is the community around the pesantren while the supporting informant is the pesantren board. To ensure the validity of the data, the writer did data triangulation.

\section{Results and Discussion}

Forms of Community Participation for Education in Pesantren Madinatul Munawwarrah

Community participation is needed in education because it enables to form public awareness about their shared responsibility for education.it does not only expect the awareness values but also expect their direct participation to create the mutual beneficial cooperation among the concerned parties in education. Besides, through the participation of the community, it can achieve effectiveness and efficiency for the better school performance.

There are several forms of community participation. According to Ericson in Slamet, the participation the community can give can be in the form of three stages ${ }^{19}$ :

1) Participation in idea planning stage. Participation in this stage means the involvement of a person in the phase of formulating the planning and strategies in arranging committee and budget for a certain activity/project. The community participates through giving suggestions, recommendations, and critics in the meeting conducted;

2) Participation in implementation stage. Participation in this stage means the involvement of a person in the implementation

\footnotetext{
18 Arikunto Suharsimi, Prosedur Penelitian Suatu Pendekatan Praktik, (Jakarta: Rineka Cipta, 2002), p.25.

${ }^{19}$ Slamet, Y, PembangunanMasyarakat..., p.97.
} 
stage of a project. In this phase, the community can provide help, money, material and ideas as one form of their participations in the given project;

3) Participation in utilization stage. Participation in this stage means the involvement of a person in the utilization phase of a project after it is completed. The community participation in this stage is in the form of providing help and money to operate and maintain the project that has been complete.

Regarding to the forms of the community participation in the pesantren, the writer interviewed one of important figures in the nearby community. Through this interview, the writer obtained the following information.

"Every time I was invited to attend events in the pesantren, I usually attended it unless I had another more important event to go to. Even though I came, I rarely gave feedback, ideas or suggestions to the pesantren. So, I did not participate in the process of formulating the programs or activities for the pesantren. Community participation here is commonly in the form of material, and it is not really in the significant amount. It is because most of the people in this community are temporary settlers." ${ }^{20}$

Among some other people interviewed, the writer obtained the similar response. Therefore, it can be concluded that the forms of community participation is material or money in the form of donation and waqf, shadaqah given directly to the pesantren.

The writer also interviewed a number of students' parents related to the forms of the community participation. The reason the writer interviewed students'parents of students is because they are also a member of community that directly involves in the educational process of the pesantren. From this interview, the writer obtained the following information.

"It is difficult for us as parents to participate especially regarding to the formulating or

\footnotetext{
${ }^{20}$ Syahrial, interview on September 6, 2015.
}

planning of pesantren activities. It is because we live far away from the pesantren and we also have a job to do every day. Sometimes, we only come to this pesantren once in a month to see our children, some of us even come once in a semester." ${ }^{21}$

To confirm these findings, the writer interviewed the principal and teacher of the pesantren. From this interview, the writer obtained information that the community does not participate in the process of formulating and planning the activities for the pesantren. Similarly, they just participate in terms of material and learning facilities, which are not significant. The assistance whether financial or facilities are commonly given by donator who are not from the surrounding community. On the other hand, some of the community member do participate in giving their ideas, suggestions, and criticism to the pesantren.

Based on the research findings above, it can be concluded that actually the community is very participating towards the Pesantren of Madinatul Munawwarah. Although the participation given to the pesantren is still limited to the material. It can be seen from the progress of this pesantren in terms of physical building boarding school. At first, this pesantren conduct learning activities in buildings owned by the city government of Bukittinggi. Due to the high attention and participation, the community finally donated the land for the construction of this pesantren building. When this research is done, this pesantren has owned its own building which is the result of self-financing and selfhelp community. Even the city government of Bukittinggi also contribute to the progress of this pesantren.

\section{Factors Influencing Community Participation for Education in Pesantren}

Factor influencing the community participation can be the internal one and external one. Internal factors come from within the community itself, the individual and the group in it. The individual behavior is closely related to

\footnotetext{
${ }^{21}$ Syukarni Syukur, interview on September 6, 2015.
} 
and determined by sociological characteristics such as age, sex, knowledge, job and income. On the other hand, according to Sunarti, external factors can be understood as the stakeholder, all interested parties who have influence in the given program. Key stakeholder is the one with the most significant influence or with the most important position for the success of the given program.

The factors influencing the community participation for education in Pesantren Madinatul Munawwarrah Bukittinggi are internal factors (education, profession, age, sexes, citizenship, and knowledge) and external factors (local government, public figures, local administrative (kelurahan RT/RW). From the interview, the writer obtained the following informantion:

a. Age: The pesantren boards explains that every activity needs to be conducted together through gotong-royong (common place activity), so the most frequently attending community members are in the age between 30-45 years. However, in religious-related activities, the most frequently attending community members are in the age 50 above.

b. The community citizenship status also influences respondents' participation in attending the meeting. Temporary settles rarely attend the events when invited by the pesantren. It shows that temporary settlers do not really care for the pesantren.

c. Factor of sexes influences the forms of donation and involvement in pesantren events. The women compared to men mostly attend every event. However, the meeting related to discussion of ideas and suggestions are mostly attended by men compared to women.

d. Factor of profession influences the form of donation and participation given. Respondents with the profession as a farmer mostly participate through physical assistance compared to the ones whose professions are merchants, self-employed, civil servant, and housewife.

e. Education influence the attendance and the involvement in the pesantren events. The respondents with educational background junior and senior high school as well as university graduates are the ones who mostly attend and actively participate.

The external factors are the role of each stakeholder related to the pesantren. In this case, the stakeholders for this pesantren local governments, local administrative, public figure, and ministry of religious affairs of Bukittinggi.

From the interview, it can be concluded that the stakeholders have played the role well. It can be seen from a large amount of assistance and donation for this pesantren from local government, ministry of religious affairs of Bukittinggi, and public figure.

\section{Efforts of Pesantren Boards to Improve Community Participation}

According to Mulyasa ${ }^{22}$, there are some efforts to mobilize community participation in education. First, proposing sanctions against those who are not willing to participate in the form of penalty, fine, and other losses. Second, proposing rewards to those who want to participate. Third, persuading the community to participate for their own benefits, both in short and in long term. Fourth, informing the community about various school activities. Fifth, correlating the community with the good school services. Sixth, asking an influence public figure to participate in school activities. Seventh, correlating the community participation in school activities with their interests. Eighth, raising the community awareness to participate in many school activities to actualize their aspirations. From the interview to the pesantren board, the writer obtained the following information.

"We as the board of this pesantren always make efforts to ask the surrounding community in particular and the people in Bukittinggi in general as well as students' parents to give their participation in this pesantren. We have made some efforts such as involving the community in many

\footnotetext{
${ }^{22}$ Mulyasa, Manajemen Berbasis Sekolah..., p. 150
} 
events or activities, raising their awareness about the importance of the pesantren, and involving important public figures in the community." 23

To confirm these findings, the writer also interviewed vice principals and some teachers.

From this interview, the writer obtained the following information.

"The principal, vice principals, and teachers of this pesantren have made efforts to increase community participation for the pesantren. Alhamdulillah, for several past years, the participation has increased in the form of material or financial donation. To increase the community participation, we invite them to wirid pengajian (religious meeting) held by the pesantren, then we urge them to give more attention to the religious schools/ pesantren. We also visit some important public figures in Bukittinggi to ask for their donation for the pesantren. ${ }^{24}$

It can be concluded that pesantren has done several efforts to increase society's participation in education through inviting and asking the society, giving awareness about the importance of religion school also involving society in some activities through influenced person too.

\section{Conclusion}

Based on the findings above, it can be concluded that at first, the forms of the community participation for education in Pesantren Madinatul Munawarrah is in the form of material, money, and physical assistance. These participation is not entirely from the surrounding community but from the donator outside them. On the other hand, the participation in the form of ideas, suggestions, and criticisms is still low. Secondly, factors influencing the lack participation of the community in the Pesantren Madinatul Munawwarrah is the factor of profession, the location of the pesantren in heterogonous community (mostly inhabited by temporary settlers), and the level of education.

\footnotetext{
${ }^{23}$ Yendra, interview on September 16, 2015.

${ }^{24}$ Syafi'i Mizan, interview on Septermber 19, 2015.
}

Third, the efforts to increase the community participation for education in the pesantren are through involving the community in many events or activities, raising their awareness about the importance of the pesantren, and involving important public figures in the community. Based on the conclusion above, it is suggested that the pesantren makes an effort to always involve the community in every event or activity from the formulation of the certain activity to its implementation. The community increases their attention and participation to Pesantren Madinatul Munawwarah, so the participation given is not only in the form of material and money but also in the form of ideas, suggestions, and criticisms to make this pesantren improve and develop so that it can become the best pesantren in Bukittinggi.

\section{References}

Davis, Keith, Human Relation Work, terj. Agus Darma, Perilaku dalam Organisasi, Jakarta: Erlangga, 2002

Dwiningrum, Siti Irene Astuti, Desentralisasi dan Partisipasi Masyarakat Dalam Pendidikan. Yogyakarta: Pustaka Pelajar, 2011.

Miarso, Yusufhadi, Menyemai Benih Tekhnologi Pendidikan, Jakarta: Kencana, 2004.

Mulyasa, Manajemen Berbasis Sekolah (Konsep, Strategi dan Implementasi), Bandung: Remaja Rosdakarya, 2006.

Nata, Abudin, Sejarah Pertumbuhan dan Perkembangan Lembaga-lembagaPendidikan Islam Indonesia, Jakarta:PT.Grasindo Gramedia Widiya Sarana Indonesia, 2001.

Ndraha,Taliziduhu, Pembangunan Masyarakat Tinggal Landas, Jakarta: Penerbit Rineka Cipta, 1990.

Prihartanto,Danang, "Partisipasi Masyarakat dalam Pengembangan Obyek Wisata (Studi Deskriptif tentang Pengembangan Pengembangan Proyek Wisata Air Terjun Jumog di Desa Berjo), 2007.

Qomar, Mujamil, Pesantren dari Transformasi Metodologi Menuju Demokratisasi Institusi. Jakarta:ERLANGGA, 1996.

RM.Mac Iver dan Charles P, Society an Introductory Analysis: Macmillan\&Co. Ltd, 1961. 
Slamet, Y, Pembangunan Masyarakat Berwawasan Partisipasi. Surakarta: Sebelas Maret University Press, 1994.

Soekonto, Soerjono, Sosiologi SuatuPengantar, Edisi Baru Keempat, Jakarta: Rajawali Pers, 1990. Suharsimi, Arikunto, Prosedur Penelitian Suatu Pendekatan Praktik, Jakarta: Rineka Cipta, 2002.
Sunarti, Partisipasi Masyarakat dalam Pembangunan Perumahan secara Kelompok, Jurnal TataLoka, Semarang: Planologi UNDIP, 2003.

Tuti T Sam, M. Chan, Kebijakan Pendidikan Era Otonomi Daerah, Jakarta: Raja Grafindo Persada, 2005. 